\title{
Editorial
}

\section{The COVID-19 variants: an overview}

\author{
Anuj K. Pandey*, Sidharth S. Mishra, Yogesh Wadgave, Nidhi Mudgil, \\ Sonal Gawande, Vijay B. Dhange
}

\begin{abstract}
Ministry of Health and Family Welfare, Government of India, Nirman Bhawan, New Delhi, India
Received: 21 July 2021

Revised: 26 August 2021

Accepted: 27 August 2021

*Correspondence:

Dr. Anuj K. Pandey,

E-mail: anuj.dr02@gmail.com

Copyright: (C) the author(s), publisher and licensee Medip Academy. This is an open-access article distributed under the terms of the Creative Commons Attribution Non-Commercial License, which permits unrestricted non-commercial use, distribution, and reproduction in any medium, provided the original work is properly cited.
\end{abstract}

The outbreak of novel coronavirus disease (COVID-19) was initially noticed in a seafood market in Wuhan city in Hubei Province of China in mid-December 2019 which has now spread to 223 countries/territories/areas worldwide. ${ }^{1}$ World Health Organization (WHO) under International Health Regulations (IHR) has declared this outbreak as a public health emergency of international concern (PHEIC) on 30th January 2020 subsequently declared a pandemic on 11th March 2020.2

As on 20th July 2021, a total of 19.7 million confirmed cases and 4.09 million deaths have been reported globally. Maximum number of cases is currently being reported from United States of America (USA), India, Brazil, Russia, United Kingdom (UK), France, Spain, Italy, Turkey, and Germany. A resurgence of cases has been reported from number of countries in Europe, Americas, Africa, and Asia Pacific. USA, India, Israel, UK, Russia, Germany, Italy, and Canada have already initiated COVID-19 immunization. ${ }^{3}$

Globally, number of new cases reported last week (12-18 July 2021) was over 3.4 million, a $12 \%$ increase as compared to the previous week. Globally, COVID-19 weekly case incidence increased with an average of around 490000 cases reported each day over the past week as compared to 400000 cases reported daily in the previous week. Following a steady decline for over two months, the number of weekly deaths reported was similar to the previous week, with almost 57000 deaths reported. ${ }^{4}$ The cumulative number of cases reported globally is now over 190 million and the number of deaths exceeds 4 million. At this rate, it is expected that the cumulative number of cases reported globally could exceed 200 million in the next three weeks. ${ }^{5,6}$

A variant is referred to as a strain when it shows distinct physical properties. In simple words a strain is a variant that is built differently and so behaves differently to its parent virus. $^{7}$

Variants of severe acute respiratory syndrome coronavirus 2 (SARS-CoV-2) may alter transmission or disease characteristics, therapeutics, or impact effectiveness of vaccines, diagnostics, or public health and social measures. This paper focuses on the above-mentioned aspects of SARS-CoV-2 variants.

\section{COVID-19 variants}

Till 2019, only six corona virus variants were known to infect humans: HCoV-229E, HCoV-OC43, SARS-CoV (SARS-CoV-1), HCoV-NL63, CoV-HKU1, and MERSCoV. A seventh, SARS-CoV-2, emerged in the winter of 2019 from Wuhan, China. SARS-CoV-2 is closely related to SARS-CoV-1, a virus that appeared from Guangdong province, China in late $2002 .^{8}$

All viruses, including SARS-CoV-2, the virus that causes COVID-19, change over time. Most changes have little to no impact on the virus' properties. However, some changes may affect the virus's properties, such as how easily it spreads, the associated disease severity, or the performance of vaccines, therapeutic medicines, diagnostic tools, or other public health and social measures. ${ }^{9}$ A variant of concern (VOC) is associated with- Increase in transmissibility or detrimental change in COVID-19 
epidemiology, increase in virulence or change in clinical disease presentation or decrease in effectiveness of public health and social measures or available diagnostics, vaccines, therapeutics. ${ }^{10}$

Systems have been established to detect "signals" of potential VOCs or variants of interest (VOIs) and assess these based on the risk posed to global public health. ${ }^{6} \mathrm{~A}$ variant of SARS-CoV-2 with a D614G substitution in the gene encoding the spike protein emerged in late January or early February 2020. Over a period of several months, the D614G mutation replaced the initial SARS-CoV-2 strain identified in China and by June 2020 became the dominant form of the virus circulating globally. ${ }^{11,12}$ Studies in human respiratory cells and in animal models demonstrated that compared to the initial virus strain, the strain with the D614G substitution has increased infectivity and transmission. ${ }^{13}$ The SARS-CoV-2 virus with the D614G substitution does not cause more severe illness or alter the effectiveness of existing laboratory diagnostics, therapeutics, vaccines, or public health preventive measures. ${ }^{11,12}$

In August and September 2020, a SARS-CoV-2 variant linked to infection among farmed mink and subsequently transmitted to humans, was identified in North Jutland, Denmark. ${ }^{14}$ The variant, referred to as the "cluster 5" variant by Danish authorities, has a combination of mutations not previously observed. Preliminary studies conducted in Denmark, suggests that this variant may result in reduced virus neutralization in humans, which could potentially decrease the extent and duration of immune protection following natural infection or vaccination. ${ }^{15}$

First, available information allows for the delineation of VOC B.1.617. B.1.617 viruses are divided in three lineages: B.1.617.1, B.1.617.2 and B.1.617.3. Available findings for lineages B.1.617.1 and B.1.617.2 were initially used to designate B.1.617 a global VOC on 11 May 2021. Since then, it has become evident that greater public health risks are currently associated with B.1.617.2, while lower rates of transmission of other lineages have been observed. To reflect this updated information, B.1.617 has been delineated as follows. ${ }^{16,17}$

B.1.617.2 remains a VOC and labelled variant delta - this variant showed increased transmissibility and a growing number of countries reporting outbreaks associated with this variant. Further studies to assess the impact of this variant remain a high priority.

B.1.617.1 has been reclassified to a VOI and labelled variant kappa - while also demonstrated increased transmissibility (in specified locations), global prevalence appears to be declining. This variant will continue to be monitored and reassessed regularly.
B.1.617.3 is no longer classified as either a VOI or VOC relatively few reports of this variant have been submitted to date.

Second, variant B.1.616, which was first detected in France following investigations into an unusual cluster of cases in a hospital, is no longer classified as a VOI. Local authorities have reported that the outbreak has been controlled, and no further detections within or outside of France have been reported since late-April 2021. Further local and regional monitoring remains prudent, given B.1.616 was associated with potential increased disease severity and reduced detections via nasopharyngeal samples. ${ }^{16,17}$

As of 20th July 2021 update by WHO, the number of countries/areas/territories reporting VOCs has continued to increase, 180 countries are reporting alpha (B.1.1.7) variant, 130 countries, territories and areas reporting beta (B.1.351) variants, whereas for gamma (P.1) and delta (B.1.617.2) the cases have spread to 78 and 124 countries/territories and areas respectively. ${ }^{4}$

On 14th December 2020, UK authorities have confirmed a variant referred to as alpha- B1.1.7 (GR/501Y.V1). ${ }^{11,17}$ This variant contains 23 nucleotide substitutions and is not phylogenetically related to the SARS-CoV-2 virus circulating in the UK at the time the variant was detected. Variant initially appeared in South East England but within a few weeks began to replace other virus lineages in the same geographic area and London. ${ }^{18,19}$

Mutations in the spike protein, which aids the virus in its effort to invade human cells (N501Y mutation). These single mutations occur in a part of the virus RNA that causes a change in a particular building block leading to increased transmission which allows SARS-CoV-2 to bind more readily to the human receptor angiotensin converting enzyme-2 (ACE-2), the entry point for SARS-CoV-2 to a wide range of human cells. ${ }^{13,18}$

This variant has been identified from routine sampling and genomic testing conducted across the UK. Preliminary epidemiologic, modelling, phylogenetic and clinical findings suggest that new variant has increased transmissibility. ${ }^{20}$ However, preliminary analyses also indicate that there is no change in disease severity (as measured by length of hospitalization and 28-day case fatality), or occurrence of reinfection between variant cases compared to other SARS-CoV-2 viruses circulating in the UK. ${ }^{14,15}$ Laboratory evaluation has demonstrated no significant impact on the performance of antigen based lateral flow devices. As on 30th December, VOC202012/01 variant has been reported in 31 other countries/territories/areas in five of the six WHO regions. ${ }^{15,21}$

It was well noted that with change in the variants, symptoms amongst the patients have also changed. Difference between variant and original strain is within the 
margin of error. A published article taking the source of U.K.'s Office for National Statistics have compared the change in symptoms mentioned in Table $1 .^{22}$

Table 1: Coronavirus symptom checker: variant versus original.

\begin{tabular}{|c|c|c|}
\hline Symptoms & $\begin{array}{l}\text { Variant } \\
(\%)\end{array}$ & $\begin{array}{l}\text { Original } \\
\text { stain }(\%)\end{array}$ \\
\hline Cough & 35 & 28 \\
\hline Fatigue/weakness & 32 & 29 \\
\hline Headache & 32 & 30 \\
\hline Muscle aches & 25 & 21 \\
\hline Sore throat & 22 & 19 \\
\hline Fever & 22 & 20 \\
\hline Loss of taste & 16 & 19 \\
\hline Loss of smell & 15 & 19 \\
\hline
\end{tabular}

As on 16th November, routine sequencing by Republic of South African (RAS) health authorities found that this new SARS-CoV-2 variant has largely replaced other SARSCoV-2 viruses circulating in the Eastern Cape, Western Cape, and KwaZulu-Natal provinces of RSA. This variant rapidly displaced other lineages circulating in RSA, and preliminary studies suggest the variant is associated with a higher viral load, which may suggest potential for increased transmissibility, this, as well as other factors that influence transmissibility, are subject of further investigation. ${ }^{7,18,21,23,24}$

On 18th December, national authorities in RSA announced the detection of a new variant of SARS-CoV-2 that is rapidly spreading in three provinces. Moreover, at this stage, there is no clear evidence of the new variant being associated with more severe disease or worse outcomes. ${ }^{7,18,21,23,24}$

On January 6th, 2021, the National Institute of Infectious Diseases (NIID) of Japan detected a new variant isolate of
SARS-CoV-2 from four travellers who arrived in Tokyo from Amazonas, Brazil, on 02 January 2021 at the airport screening. The new variant isolate belongs to B.1.1.248 lineage and has 12 mutations in the spike protein, including $\mathrm{N} 501 \mathrm{Y}$ and E484K. The isolate has some mutations found in previously reported variant isolates of concern from the UK and South Africa. ${ }^{25,26}$

\section{Vaccination and variant}

The COVID-19 vaccines those already approved or the one which are currently in development are expected to provide at least some protection against new virus variants because these vaccines provide a broad immune response involving a range of antibodies and cells. Therefore, changes or mutations in the virus should not make vaccines completely ineffective. In the event that any of these vaccines prove to be less effective against one or more variants, it will be possible to change the composition of the vaccines to protect against these variants. ${ }^{27}$

While most LMICs had experience with conducting mass vaccination campaigns, infection prevention and control (IPC) at vaccination sites added some challenges to maintain a smooth workflow. Countries provided safe spaces for observation of vaccines for severe allergic reactions following vaccination, and trained personnel and provided supplies to manage such reactions. Several countries reported lower than expected turn-out at sessions due to vaccine hesitancy, resulting in a high volume of open vials to be wasted. ${ }^{10}$

\section{Public health response to variants}

The authorities in the affected countries had epidemiological and virological investigations to further assess the transmissibility, severity, risk of reinfection and antibody response to new variants. ${ }^{11}$

Table 2: Comparison of SARS-COV variants strain.

\begin{tabular}{|c|c|c|c|c|c|c|c|c|c|}
\hline & 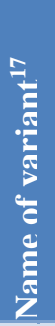 & 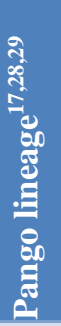 & $\begin{array}{l}\text { Fe } \\
\frac{0}{0} \\
\frac{\pi}{0} \\
\frac{2}{0} \\
\frac{0}{0}\end{array}$ & 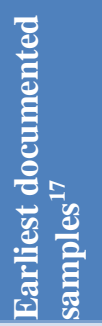 & 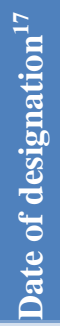 & Diagnosis $^{1}$ & $\begin{array}{l}\text { Transmissibilit } \\
\mathbf{y}^{17,30,31}\end{array}$ & Severity ${ }^{17,30}$ & $\begin{array}{l}\text { Vaccine } \\
\text { response } \\
6,32\end{array}$ \\
\hline \multirow{2}{*}{ 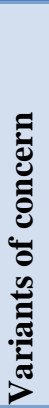 } & $\frac{\frac{\pi}{E}}{\frac{E}{L}}$ & 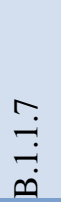 & $\begin{array}{l}\frac{\lambda}{\bar{\Xi}} \\
\frac{\pi}{0} \\
0\end{array}$ & 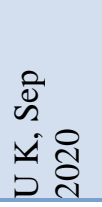 & 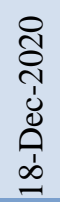 & $\begin{array}{l}\text { Limited } \\
\text { impact }\end{array}$ & $\begin{array}{l}\text { Increased } \\
\text { transmissibility } \\
\text { and secondary } \\
\text { attack rate }\end{array}$ & $\begin{array}{l}\text { Possible } \\
\text { increased risk of } \\
\text { hospitalization, } \\
\text { severity, and } \\
\text { mortality }\end{array}$ & $\begin{array}{l}\text { Protection retained against } \\
\text { disease }\end{array}$ \\
\hline & $\frac{\pi}{2}$ & $\begin{array}{l}\vec{n} \\
\ddot{n} \\
\ddot{n}\end{array}$ & 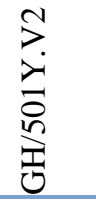 & 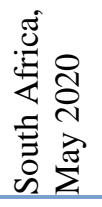 & 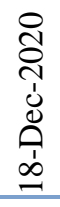 & $\begin{array}{l}\text { No impact } \\
\text { on RT- } \\
\text { PCR or Ag } \\
\text { RDTs }\end{array}$ & $\begin{array}{l}\text { Increased } \\
\text { transmissibility }\end{array}$ & $\begin{array}{l}\text { Possible } \\
\text { increased risk of } \\
\text { in-hospital } \\
\text { mortality }\end{array}$ & $\begin{array}{l}\text { Reduced protection against } \\
\text { disease; limited evidence }\end{array}$ \\
\hline
\end{tabular}




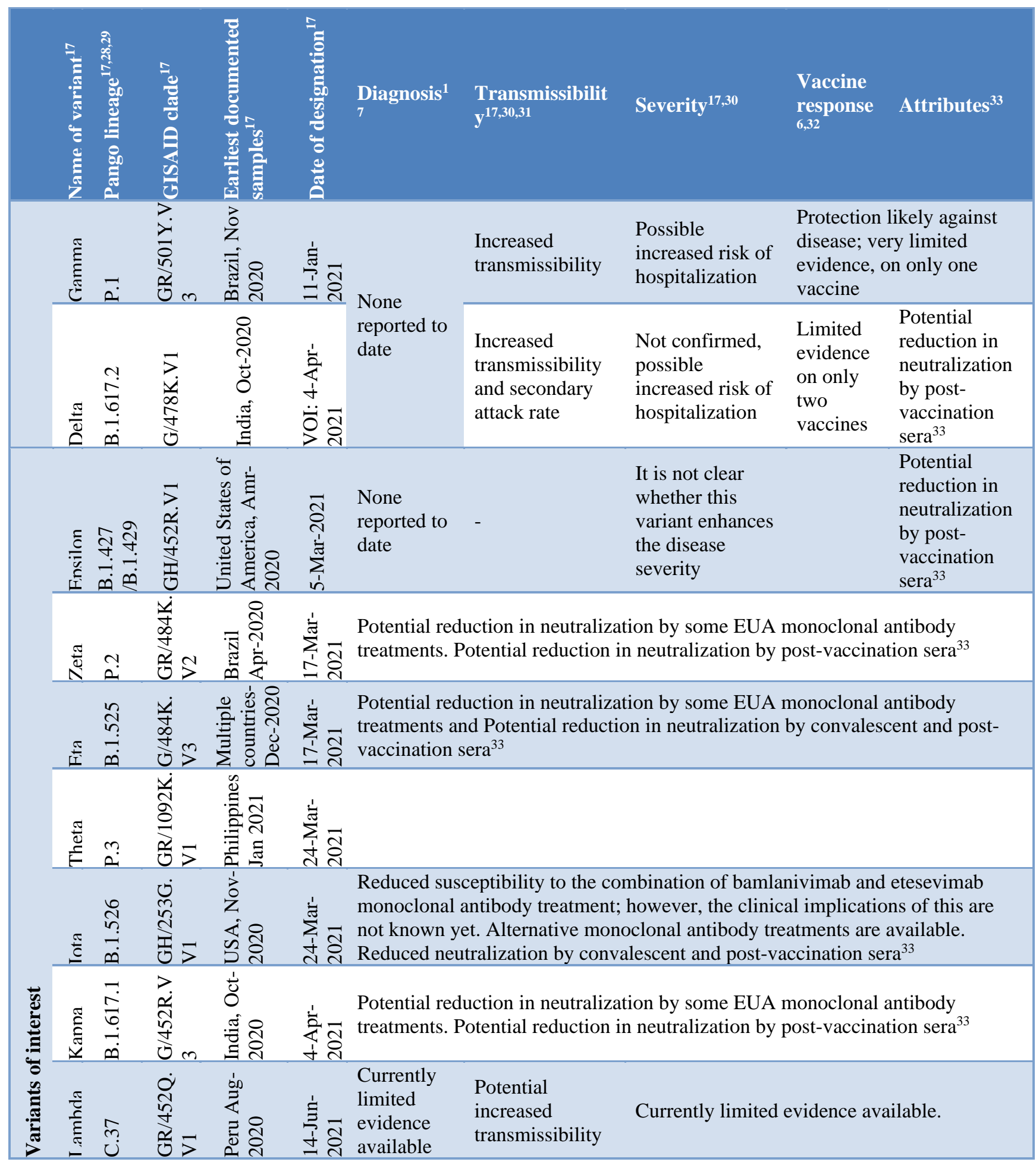

Table 3: IPC guidance and measure available.

\begin{tabular}{|ll|}
\hline SI no. & Infection prevention and control guidance and measures should reinforced \\
\hline $\mathbf{1}$ & $\begin{array}{l}\text { Use appropriate personal protective equipment when caring for people suffering from an acute respiratory } \\
\text { illness }\end{array}$ \\
\hline $\mathbf{2}$ & \begin{tabular}{l} 
Practice frequent handwashing, especially after direct contact with ill people or their environment \\
\hline $\mathbf{3}$
\end{tabular} \\
$\begin{array}{l}\text { Practice cough etiquette (maintain distance, cover while coughing and sneezes with disposable tissues or } \\
\text { clothing, and wash hands) }\end{array}$ \\
\hline $\mathbf{4}$ & Enhance standard IPC practices in hospitals \\
\hline $\mathbf{5}$ & Wear masks where appropriate, ensure good ventilation where possible and avoid crowded places \\
\hline
\end{tabular}


The following activities have been initiated by the authority: intensified sampling to understand how widely these new variants are circulating; effect of the mutations on reinfection potential, vaccination, diagnostic testing, infection-severity, and transmissibility are being studied; researchers and government authorities are working to understand virus evolution working group to assess epidemiologic, modelling, phylogenetic and laboratory findings as results become available; strengthening of surveillance systems to evaluate potential virus variations through ongoing systematic clinical and epidemiologic surveillance; establishment of genetic sequencing capacity where possible; providing access to international sequencing services to send samples for sequencing and phylogenetic analysis; and risk communication and community engagement activities scaled up to explain the public health implications of SARS-CoV-2 variants to the public and emphasize the importance of maintaining ongoing preventive measures to reduce transmission (Table 3). ${ }^{2,11-13,25,26,34}$

\section{CONCLUSION}

Although the number of cases and deaths have been decreasing for over a month, we are witnessing a two-track pandemic: where many countries still face an extremely dangerous situation, while some of those with the highest vaccination rates are starting to talk about ending restrictions. It is essential to make this very clear that the pandemic is not over, and it will not be over until and unless transmission is controlled in every last country. Virus evolution is an expected phenomenon, and the more SARS-CoV-2 circulates, the more opportunities it has to evolve.

The inequitable distribution of vaccines has allowed the virus to continue spreading, increasing the chances of a variant emerging that renders vaccines less effective and the biggest barrier to ending the pandemic remains sharing: of doses, of resources, of technology. The emergence of more transmissible variants means public health and social measures may need to be more stringent and applied for longer, particularly in areas where vaccination rates remain low. The tailored and consistent use of public health measures, in combination with equitable vaccination, remains the way out.

\section{REFERENCES}

1. Coronavirus disease (COVID-19) - World Health Organization. Available at: https://www.who.int/ emergencies/diseases/novel-coronavirus-2019. Accessed on 02 March 2021.

2. Statement on the second meeting of the International Health Regulations (2005) Emergency Committee regarding the outbreak of novel coronavirus (2019. nCoV). Available at: https://www.who.int/ news/item/30-01-2020-statement-on-the-secondmeeting-of-the-international-health-regulations(2005)-emergency-committee-regarding-the- outbreak-of-novel-coronavirus-(2019-ncov).

Accessed on 02 March 2021.

3. WHO Coronavirus Disease (COVID-19) Dashboard. Available at: https://covid19.who.int. Accessed on 02 March 2021.

4. Weekly epidemiological update on COVID-19 - 20 July 2021. Available at: https://www.who.int/ publications/m/item/weekly-epidemiologicalupdate-on-covid-19---20-july-2021. Accessed on 21 July 2021.

5. Weekly epidemiological update on COVID-19 - 6 July 2021. Available at: https://www.who.int /publications/m/item/weekly-epidemiologicalupdate-on-covid-19---6-july-2021. Accessed on 07 July 2021.

6. Weekly epidemiological update on COVID-19 - 15 June 2021. Available at: https://www.who.int/ publications/m/item/weekly-epidemiologicalupdate-on-covid-19---15-june-2021. Accessed on 18 July 2021.

7. Lauring AS, Hodcroft EB. Genetic Variants of SARS-CoV-2-What Do They Mean? JAMA. 2021;325(6):529.

8. Zhang L, Jackson CB, Mou H, Ojha A, Rangarajan ES, Izard T, et al. The D614G mutation in the SARSCoV-2 spike protein reduces $\mathrm{S} 1$ shedding and increases infectivity. bioRxiv. 2020.

9. Tracking SARS-CoV-2 variants. Available at: https://www.who.int/activities/tracking-SARS-CoV2-variants. Accessed on 18 July 2021.

10. COVID-19 Weekly Epidemiological Update. Available at: https://www.who.int/publications/m/ item/covid-19-weekly-epidemiological-update. Accessed on 18 July 2021.

11. WHO | SARS-CoV-2 Variants. Available at: http://www.who.int/csr/don/31-december-2020-sarscov2-variants/en/. Accessed on 02 March 2021.

12. WHO | Variant analysis of SARS-CoV-2 genomes. Available at: http://www.who.int/bulletin/volumes/ 98/7/20-253591/en/. Accessed on 12 March 2021.

13. Hou YJ, Chiba S, Halfmann P, Ehre C, Kuroda M, Dinnon KH, et al. SARS-CoV-2 D614G variant exhibits efficient replication ex vivo and transmission in vivo. Science. 2020;370(6523):1464-8.

14. Technical_Briefing_VOC202012-2_Briefing_2.pdf. Available at: https://assets.publishing.service.gov.uk /government/uploads/system/uploads/attachment_da ta/file/959361/Technical_Briefing_VOC202012-

2_Briefing_2.pdf. Accessed on 02 March 2021.

15. Technical_Briefing_VOC_SH_NJL2_SH2.pdf. Available at: https://assets.publishing.service.gov.uk /government/uploads/system/uploads/attachment_da ta/file/959438/Technical_Briefing_VOC_SH_NJL2 _SH2.pdf. Accessed on 02 March 2021.

16. Weekly epidemiological update on COVID-19 - 1 June 2021. Available at: https://www.who.int/ publications/m/item/weekly-epidemiologicalupdate-on-covid-19---1-june-2021. Accessed on 18 July 2021. 
17. Weekly epidemiological update on COVID-19. 2021. Available at: https://www.who.int/publications/ $\mathrm{m} /$ item/weekly-epidemiological-update-on-covid19---8-june-2021. Accessed on 18 July 2021.

18. Brief TA. Rapid increase of a SARS-CoV-2 variant with multiple spike protein mutations observed in the United Kingdom. 2020;13.

19. Statement on the meeting of the International Health Regulations (2005) Emergency Committee regarding the outbreak of novel coronavirus 2019 (n-CoV). Available at: https://www.who.int/news/item/23-012020-statement-on-the-meeting-of-the-internationalhealth-regulations-(2005)-emergency-committeeregarding-the-outbreak-of-novel-coronavirus-(2019ncov). Accessed on 18 July 2021.

20. Variants_of_Concern_VOC_Technical_Briefing_6_ England-1.pdf. Available at: https://assets. publishing.service.gov.uk/government/uploads/syste m/uploads/attachment_data/file/961299/Variants_of _Concern_VOC_Technical_Briefing_6_England1.pdf. Accessed on 18 July 2021.

21. Investigation of novel SARS-CoV-2 variant - Variant of Concern. 2020;19.

22. Crouch M. New COVID Strain Brings More Symptoms, More Infections. AARP. Available at: https://www.aarp.org/health/conditions-treatments /info-2021/coronavirus-variant-symptoms.html. Accessed on 18 July 2021.

23. Volz E, Hill V, McCrone JT, Price A, Jorgensen D, O'Toole Á, et al. Evaluating the Effects of SARSCoV-2 Spike Mutation D614G on Transmissibility and Pathogenicity. Cell. 2021;184(1):64-75.

24. Plante JA, Liu Y, Liu J, Xia H, Johnson BA, Lokugamage KG, et al. Spike mutation D614G alters SARS-CoV-2 fitness. Nature. 2020;592:116-21.

25. Nonaka CKV, Franco MM, Gräf T, Mendes AVA, Aguiar RS de, Giovanetti M, et al. Genomic Evidence of a Sars-Cov-2 Reinfection Case With E484K Spike Mutation in Brazil. 2021;2021010132.

26. Comprehensive mapping of mutations to the SARSCoV-2 receptor-binding domain that affect recognition by polyclonal human serum antibodies | bioRxiv. Available at: https://www.biorxiv.org /content/10.1101/2020.12.31.425021v1. Accessed on 18 July 2021.

27. The effects of virus variants on COVID-19 vaccines. Available at: https://www.who.int/news-room/ feature-stories/detail/the-effects-of-virus-variantson-covid-19-vaccines. Accessed on 18 July 2021.

28. Centers for Disease Control and Prevention. COVID19 and Your Health. 2020. Available at: https://www.cdc.gov/coronavirus/2019-ncov/transm ission/variant.html. Accessed on 18 July 2021.

29. Difference between a coronavirus variant and strain Los Angeles Times. Available at: https://www. latimes.com/science/story/2021-02-04/whatsdifference-between-variant-strain-coronavirus. Accessed on 18 July 2021.

30. Solutions for surveillance of the $S$ gene mutation in the B.1.1.7 (501Y.V1) SARS-CoV-2 strain lineage Behind the Bench. Available at: https://www. thermofisher.com/blog/behindthebench/solutionsfor-surveillance-of-the-s-gene-mutation-in-theb117-501yv1-sars-cov-2-strain-lineage $/$ ?cid= gsd_cbu_sbu_r04_co_cp1422_pjt6968_gsd00000_0 se_gaw_ta_lgn_em-b117-. Accessed on 18 July 2021.sars\&gclid=Cj0KCQjw0caCBhCIARIs AGAfuMyD8k5oAqTDhUEsGChZxns5XvBV14tm XA_zjfyVR-K8hfj42IVO2BYaAt62EALw_wcB. Accessed on 18 July 2021.

31. COVID-19 - Variants \& Vaccines. Available at: https://www.who.int/emergencies/diseases/novelcoronavirus-2019/media-resources/science-in-5/epi sode-20---covid-19---variants-vaccines. Accessed on 18 July 2021.

32. Here's what you need to know about the new COVID-19 strains. Available at: https://news.vcu. edu/article/Heres_what_you_need_to_know_about_t he_new_COVID19_strains. Accessed on 18 July 2021.

33. Centers for Disease Control and Prevention. Coronavirus Disease 2019 (COVID-19). Available at: https://www.cdc.gov/coronavirus/2019-ncov/var iants/variant-info.html. Accessed on 18 July 2021.

34. Covid-19: What have we learnt about the new variant in the UK? The BMJ. 2020;371.

Cite this article as: Pandey AK, Mishra SS, Wadgave Y, Mudgil N, Gawande S, Dhange VB. The COVID-19 variants: an overview. Int J Community Med Public Health 2021;8:5148-53. 